\title{
Arab Spring Failure: A Case Study of Egypt and Syria
}

\author{
Raid Khan ${ }^{1-2}$, Amna Mahmood ${ }^{3}$ and Asif Salim ${ }^{4 *}$
}

1. Department of Politics \& International Studies, SOAS University of London, United Kingdom.

2. Department of International Relations, University of Peshawar, Peshawar Pakistan.

3. Department of Politics \& International Relations, International Islamic University, Pakistan.

4. Department of Political Science, Bacha Khan University, Charsadda, Pakistan.

\begin{abstract}
The Arab Spring was assumed to reform the prevailing regime pattern and to bring socioeconomic reforms. However, it failed to get its intended outcomes at large. The objectives of the revolution that are to bring a positive transformation in the social, economic, and political domains were not attained effectively and was considered a failed revolution in the case of Egypt and Syria. The present paper focuses on exploring the reasons and factors behind its failure in the particular context of Egypt and Syria. Although Egypt observed regime transition from dictatorship to democracy, yet within one and a half year, a military coup overthrew the democratically elected government of Mohammad Morsi, and the military regime was reinstalled. In the case of Syria, since 2011, a civil war is going on where Bashar-ul-Asad still holds dictatorial powers. The study reveals that the lack of stable political institutions, weak democratic norms, and the absence of a vibrant civil society paved the way for state authorities to rule out the attempts of protestors. Excluding a few of the countries, the rest of the Middle Eastern countries are still ruled by the powerful elites. The successes of the Arab Spring are still to be awaited.
\end{abstract}

Keywords: Arab Spring, Revolution, Middle East, Civil War, Uprising, Regime Transition.

\section{Introduction}

The Arab Spring that astonished the whole world is referred to a period of protests and revolutions, which started on December 18, 2010, in Tunisia. In addition, quickly out broke to several other Middle Eastern and North African countries and caused regime changes in Tunisia, Egypt, Libya, and Yemen. Some other countries, like Syria, Bahrain, Sudan, saw repression, resilience, and violence. It was thought to bring revolutionary changes in the entire Arab world. Accordingly, some dictatorial regimes were overthrown too due to large-scale protests, but it did not change the structure of the society as expected from a revolution. Arab Spring was a failure in a sense where it was expected that the decades' old authoritarian regimes could be easily reversed and replaced with stable democratic systems across the entire region. It has also disappointed those who hoped that the removal of corrupt rulers would cause an instant improvement in living standards. The persistent instability in countries undergoing political transitions has put additional strain on struggling local economies, and deep divisions have emerged between the Islamists and secular Arabs (Manfreda, 2011). 
The situation in the Arab world does not seem stable after the revolutions. Not a single country is yet plainly on course to become a stable and peaceful democracy. Tunisia, Libya, and Yemen appeared to transform the socio-political structure better and a hope was in the offing; they are still struggling. On the one hand, Egypt has to face an unpleasant experiment with democracy, where an elected president was sent behind bars. On the other, Syria is engulfed with the blood of civil war. Most of the people now curse the Arab Spring and term it to be ill fated for the Arab world. They believe that the Arab world is not yet ready for the change. One of the reasons they quote is that as there were no democratic institutions, hence people's power cannot be channelized, which ultimately will result in chaos and dictatorship again (Tariq, 2012). The other reason is that Islam, the religion of this region, is not compatible with democracy (Tessler, 2002). The Middle East, it is now believed, would have been much better if the Arab Spring had never happened at all (The Economist, 2013).

During the period of the Arab Spring, many scholars focused on the resilient nature of the Arab monarchies to the political challenges. Most of the ruling monarchs can be found in the Arab world where more than a third of the Arab league is ruled by them (Anderson, 1991:1). The case remains the same. The Arab Spring though affected the major monarchies of the Middle East, but the monarchies of Morocco, Jordan, Saudi Arabia, Oman, Kuwait, the United Arab Emirates, Qatar, and Bahrain have all remained almost unaffected in the wake of the Arab Spring (Kühnhardt, 2012:58; Tétreault 2011:629; Jones 2013). Different arguments are provided to the resilient nature of the Arab monarchs. According to Anderson, it is because of regional exceptionalism and cultural determinism. Monarchy in the Islamic world is of a traditional type. On the other hand, it is believed that the Arab monarchies were an instrument of European imperial policy, mainly the British. It is also to be noted here that all the monarchies and republics are considered a product of the twentieth century (Anderson, 1991:2, 11). Elliot Abrams (2012) stance is that the strength and legitimacy of the Arab monarchies is because of their historical connection. According to him, monarchies in the Arab world are sustained by religious belief rather than by self-appointed strongmen (Abrams, 2012: 27). Anderson further states that even most of the republican regimes in the Arab world imitate the monarchies and are so-called "presidential monarchies". Here a strongman dominates a state with relatively few stable political institutions (Anderson, 1991:11). This is best exemplified by a very famous quote from the former Tunisian President Bourguiba where he was once asked by a journalist in the 1960s about Tunisia's political system. He exclaimed, "The system? What system? I am the system!" (Moore, 1965:51). This almost was the nature of the majority of the Arab monarchs.

Another factor elaborated in the literature related to Arab Spring is economy and modernization. A number of economic factors believed to feed unrest in the Arab world. Unemployment, youth population, decades' long dictatorial regimes, corruption etc. added to the vulnerabilities to the revolution in the Arab world (Salih, 2013:187). The deteriorating food security and living standards in the region are said to have led to the uprisings (Breisinger et al., 2011). The Arab Spring in terms of a "youth revolution" is discussed by some scholars as they focused only on the youth population. The high unemployment rate among young people in this region is seen as a significant problem, with youth unemployment as high as $80 \%$ in some areas. Frustration among the youth population because of lack of jobs and other economic opportunities make them prone to protest (Hoffman \& Jamal, 2012:169, 184). Lack of economic freedom in the Arab countries, according to Emmanuel Martin, is another forgotten cause for the Arab Spring. The government policies required tremendous administrative steps 
to set up a formal business, which Martin sees as a part of the political oppression and authoritarianism in these countries (Martin, 2012: 94).

Available literature also suggests modernization to be a possible explanation for the Arab Spring. Randall Kuhn (2012) uses the modernization theory when analysing the Arab Spring. Kuhn is of the view that no other developing region has seen such improvements in human development, for instance, declining child mortality, increased schooling, and longevity. Such type of development brings in higher expectations among the citizens on the government, including the right to self-determination. In his conclusion, he suggests that this might eventually lead to a democratic change (Kuhn, 2012:674-77). Filipe R. Campante and David Chor (2012) other two scholars break down the modernization theory and decide to focus on education as an underlying mechanism. They discuss the interaction between schooling background and economic circumstances, and especially the scarcity of job opportunities for university graduates. They further describe how the pace of growth, i.e., modernization, does not keep up with the education profile of its population (Campante \& Chor, 2012). Looking at the factors leading to the Arab Spring, the scholars do not make a definite conclusion of their result, but the result displays how factors as youth population, unemployment, economic growth, and education, are all intertwined. In the case of Morocco, Badimon makes a similar connection between the high unemployment among university graduates and the social unrest during the Arab Spring. However, many of the university graduates were reluctant to join any political alliance against the government, as there was a risk that this would jeopardize their chances of being hired in the public administration (Badimon, 2013).

The literature review indicates the role of the armies in the Arab uprisings that have been analysed by the authors as how the armed forces acted differently in the Arab countries. It is because of the role of the armies that for instance, suggested that there comes the variation between the outcomes of the different countries during the Arab Spring. This is exemplified by the cases of Tunisia and Egypt, where the army in one way facilitated the overthrowing of the governments, while there was stronger military resistance against the protesters in countries like Libya and Syria (Frisch, 2013; Salih, 2013). Ellen Lust (2011) does instead look at the relationship between Islam and democratization. She means that it is not the religion itself that stalled the "third wave of democratization" during the Arab Spring, but it was instead the fear of political Islam. This fear was used by the regime to drive a wedge between Islamic and secularist opposition groups in order to weaken their efforts to struggle against the regime (Lust 2011:186-188). The literature thus is full of the causes of the Arab Spring but do not elaborate case studies to clearly analyze the causes of failure of the Arab Spring.

\section{Research Methodology}

The research is qualitative in nature in which already available facts and information about the contents have been critically analysed. The data is based on secondary sources, as it was not possible to collect primary data due to a lack of resources. Secondary data includes various books, magazines, experts' discussions, research articles, websites, and newspapers. Like other doctrinal and security studies, this research does not claim to address the issue in its completeness; however, one of the way forward to understand the fault lines emerged after the Arab Spring in Egypt and Syria that changed entirely Middle Eastern Politics. Several research articles, newspapers, and books related to Arab Spring were examined to investigate the reasons behind its failure generally and in the case of Egypt and Syria more specifically. Most of the previous research on this scholarship highlights the general causes and factors that 
contributed to the occurrence of the Arab Spring. However, they did not pay much attention to analyse the reason in its success and failure variation between the countries. Many of the articles talked about causes and the outcomes of the Arab Spring or revolution and pondered as it will transform the entire political, economic, and social structure of the Middle East, but they have missed the failure option. Most of the literature only emphasizes the factors that brought about the revolutionary changes or were the main components that instigated the oppressed people of the Middle East to lead to the Arab Spring.

\section{Impact of Arab Spring on the Middle East}

The Middle East has dramatically been affected by the Arab Spring. Its impact is visible in the sense that in most of the cases, it brought chaos and instability in the region (The Economist, 2013, July 13). The outcome of the Arab Spring might not become visible for at least a generation. Early 2011 saw protests throughout the region, which initiated the long-term process of socio-political transformation in the Arab world. This resulted primarily in conflicts, economic hardships, and political turbulence. The significant impact of the Arab Spring was that it was realized that people's power could remove no matter how strong a dictator is. It was shown to the world that grassroots popular revolt could remove a dictator without a military coup or foreign intervention as was practiced in the past (Manfreda, 2011). The popular revolt swept away the governments in Tunisia, Egypt, Libya, and Yemen by the end of 2011. Even those who were successful in clinging to the power, they realized that corruption, incompetence, and police brutality could no longer be left unquestioned. They were forced to bring certain reforms to acquiesce to the people's grievances such as Algerian and Morocco's state officials done.

Political activities flared up in the Middle East after the Arab Spring revolt, especially in countries where it was successful in removing the long-serving dictators. With the transformation in the political landscape and no ban on media and political activities in the country, hundreds of political parties, civil society groups, newspapers, TV stations emerged from the darkness of oppressive regimes. In Libya, under Col. Muammar al-Qaddafi's regime, there were no political parties. For decades, all the political parties were banned. In the 2012 parliamentary elections, about 374 party lists contested in the elections (Manfreda, 2011). The outcome of the elections was in a diverse shape as the political landscape ranged from far-left organizations to liberals and hard-line Islamists. In the emerging democracies such as Libya, Egypt, and Tunisia, voters are confused when faced with a large number of choices. Political institutions and democratic norms to be developed in these countries will take time where children of the Arab Spring develop firm political allegiances.

The hope that this revolution in the Middle East will produce stable democratic systems was shattered quickly. The result was the emergence of deep division among the people over the new constitution and political reforms. Division within the society emerged where people divided into Islamist and secular camps that bitterly fought on the role of Islam in politics and society (Ramadan, 2011, 14). Consequently, deep mistrust arose among the people where it was believed that whoever comes to power would follow their own manifesto and objectives. The mentality of the people was that of a winner take all where there seemed to be having no room for a compromise. It thus became evident that the socio-political and religious divisions of the society, which was swept under the carpet by the former dictatorial regimes, have been uncovered by the Arab Spring, which instigated a prolonged period of political instability in the region. 
Post Arab Spring scenario did not develop as was hoped by the revolutionary elements. With the breakdown of old, order chaos and armed conflict erupted. The change was not like that of Communist Eastern Europe, which they experienced at the end of the 1980s where they gave up with the old system and welcomed the liberal democratic system. The Arab world was not ready to give up the old system easily. Civil war erupted in Libya and Syria; the conflict ended with the victory of the anti-government rebels with the support and intervention of the NATO alliance and the Arab Gulf states. In the Syrian case, the situation was worsened. A multireligious society is ruled by the most oppressive Arab regime. Civil war erupted in Syria after an unsuccessful revolutionary attempt to overthrow Bashar-ul-Asad regime. The uprising in Syria resulted in a prolonged, brutal civil war because of the outside interference (BBC News, 2016, March 11).

Sectarian tensions and conflict cannot be ruled out in all these situations in the Arab world. Muslims in the Arab world is primarily divided into Sunni and Shiite factions. The tension between them in the Middle East is on the rise since 2005, where the two factions of Islam erupted into violence in large parts of Iraq. This conflict was reinforced in the Arab world after the Arab Spring. Uncertainty related to political changes in the Middle East created fear and confusion in the minds of the people where people tried to take refuge in their own religious community. This division within the religious minorities led to protests and violence, as in the case of Bahrain and Syria. In the Sunni led Bahrain, Shiite majority demanded more political, social rights and justice. Whereas in Syria, the Shia led minority government of the Alawite was faced with resistance and protests by the Sunni majority population, which ultimately resulted in the eruption of a civil war in Syria (Valbjorn, 2019).

\subsection{Case Study of Egypt}

Protests and strikes in Egypt began on January 25, 2011. A wide section of Egyptian society took an active part in these protests including the Islamists, secularists, feminists, and many others. Police brutality, unemployment, corruption, media censorship were some of the major causes behind these protests against the authoritarian regime of President Hosni Mubarak. Where hundreds died and thousands injured in the protest because of the clashes between the protestors and the police force. President Mubarak, who had been ruling Egypt since 1981 was toppled down from his office on February 11, 2011, and was sentenced to life imprisonment in June 2012 based on the allegations of protestor deaths but was released in August 2013 by the post-coup military government (Mulholland, 2013).

President Mohammed Morsi, Egypt's first democratically elected president who came to power after the Arab Spring movement in 2011-12, legalized the Muslim Brotherhood party (Ajami, 2011). However, in 2013, the political crisis in Egypt was worsened, which led to a military coup and resulted in ousted of the Morsi government. Muslim Brotherhood was banned by the military government and all its activities were termed as illegal. It was declared by the militaryled government that whoever participated in Brotherhood activities or supported verbally or in writing or finances, its activities could go in prison for five years. Fellowship's daily newspaper, Freedom and Justice's publication were suspended (Hill, 2013).

The stance of the military-backed government regarding banning the Muslim Brotherhood and terming its members as terrorists was because of its involvement and accelerating deadliest attacks like the bombing in the Nile Delta city of Mansoura(The Guardian, 2013, December 25). All these allegations were denied by the Brotherhood leadership, and the government, on 
the other hand, could not provide any evidence of their involvement in these incidences (Heraldnet, 2013, December 25). President Morsi's policies of empowering Brotherhood and enacting regulations to enshrine Islamic laws alarmed the secular Egyptians. The widespread protests against Morsi's government led the Egypt's army to wrest power from Morsi (Kingsley, 2013, June 30).

There seems to be no chance of reconciliation between the Brotherhood and the current government after it has been declared as a terrorist organization by the government. This does not mean that the Brotherhood will cease its operations as it has hundreds of thousands of members who are loyal to the organization and committed to serving the community by engaging in social welfare activities. The government forces, on the other hand, already have arrested thousands of Brotherhood members, including its top leadership. It is also violently halted protests, leaving hundreds dead in the crackdowns. The group will almost certainly be forced to go underground - or rather, even further underground. All these are nothing new to the Brotherhood movement. In the past, it was declared illegal in the 1950s, where it focused on charitable activities for decades to come into prominence after the ouster of Mubarak (Mulholland, 2013).

The current government, after deposing Morsi, banned the organization and inflicted severe punishments on the members of the movement. Under its anti-terrorism laws, leading a Brotherhood protest will now be punishable by life in prison. The government has warned that even promoting or remaining a member of the group will be punishable. However, it is highly unlikely that all of the Brotherhood's members will turn their back on the organization now and start supporting the army. It is more likely to harden the resolve of some. Revolution in Egypt failed and could not succeed in bringing democratic institutions to flourish as Muslim Brotherhood lacked experience of governing. Husni Mubarak in his long dictatorial regime did not let the other political institutions to be established. The only institution that remained strong and well established during his rule was the military. It is because of this reason that failure of Morsi to provide alternative plausible solutions to the governance of his country and workable policies led to military coup.

\subsection{Case Study of Syria}

In the case of Syria, after the Arab Spring, the situation was not that much different and no possibility of transforming the Syrian government into a democratic setup. The uprising in Syria began in March 2011 where anti-government elements started protests against the government of Bashar al-Assad. The response of Assad's government to the protests was much harsh where peaceful protestors were met with a bloody crackdown. After a year and a half, the situation was worsened where civil war erupted between the opposition and the government elements. Most of the army officials defected and started guerrilla warfare against the government forces. The armed group of the army defectors escalated civil war up to such an extent that it reached the capital Damascus and the commercial hub Aleppo. Though many senior officers deserted Assad, there are many army units loyal to Assad. The situation got worsened when Assad forces used chemical weapons, which brought the US on the brink of intervention in the Syrian conflict. Russia, a close ally of Assad came to the forefront and brokered a deal by terms of which Syria will hand over its stockpile of chemical weapons (BBC News, 2013). Still, the scenario in Syria is of concern where the civil war is continued and hundreds and thousands of people are affected. The Russian interference is seen as a triumph of their diplomatic success in the Middle East region. 
Bashar al Assad has been in power since 2000, who inherited power from his father Hafez alAssad (1971-2000), who was an army officer and assumed the presidency is a result of a military coup in 1970. Bashar al-Assad, like his father, heavily relied on Baath Party, army, intelligence apparatus, and the well-off leading business families of the country. As being Alawites, most of the dominant positions in the government are reserved for this community. The real power lies in the hands of a small circle of Assad family members. Thus, the Alawites community dominates the security apparatus who are very loyal to the president and firmly in opposition to the majority Sunnis (Dam, 1979). The suppression of the majority Sunnis by the minority Alawites resulted in great resentment and frustrations among the Sunnis. For decades, they have been suppressed and not allowed to rise to prominence in Syrian politics. The uprising in March 2011 gave impetus to the explosion of political activities. Protests and the political uprising were brutally suppressed by the Bashar al-Assad regime, which resulted in the civil war in Syria. Initially, the protests were peaceful where people were demanding democratic reforms and end of repression, but the brutal response of the military to the peaceful protests ignited violent reactions. Soon the whole of Syria was dragged into a civil war where the armed rebellion started against Assad's forces.

In August 2012, Kofi Annan, who was an UN-Arab League Joint Special Representative for Syria, resigned from the task of resolving the issue of Syria because of the failure of the UN to progress on the issue. (Doyle, 2012). The reason was that of the powerful international actors' involvement in the Syrian crisis. There was a disagreement between Russia, a close Syrian ally, and the West. United States, who is at odds with Syria because of her alliance with Iran, has reiterated its stance that Assad should resign. Whereas on the other hand Russian stance is that it is the internal matter of Syria and that, they should decide the fate of their government. The civil war in Syria aggravated where Gulf Arab countries and Turkey supports the rebel forces against Assad's regime. On the other side, Russia gives weapons and diplomatic support to Syria and Iran, which is also Assad close ally, provides financial support (Yan, 2013; Zehra, Fatima, \& Khan, 2018).

Arab Spring is the cause of conflict in Syria, where a series of anti-government protests started across the Arab world. These protests were inspired by the fall of the Tunisian regime in early 2011. The root cause of the conflict seems to be unemployment, corruption, state violence, and long rule of the dictators where ordinary people were not allowed to have a say in governmental affairs. Geographically Syria is at the heart of Levant and followed an independent foreign policy that has made an important country in the eastern part of the Arab world. It is in close alliance with Russia and Iran and conflicted with Israel since 1948 with the creation of the Jewish state. Syria sponsored the Palestinian resistance groups against Israel. During conflicts with Israel, it has lost Golan Heights, which is under Israeli occupation. A religiously mixed community, Syria having a significant division of Sunni and Shiite population, has witnessed sectarian nature of violence, which also has contributed to wider Sunni-Shiite tension in the Middle East. The international community is much worried about the current situation in Syria, where they believe that the crisis may expand or affect the neighbouring countries of Jordan, Lebanon, Iraq, and Turkey. It is because of this reason that the US, Russia, and the European Union play an essential role in resolving the Syrian conflict (Zikriya, Khan, \& Salim, 2019).

The post Arab Spring scenario in Syria is very much chaotic and full of turbulence. Assad's forces are in the continuous fight against the hard-line Islamist rebels. It is now believed that if in a case, Assad leaves his power, instability, and civil war among different minority groups will prevail in Syria. The civil war in Syria has become so intense that it displaced hundreds 
and thousands of its people and left many injured and dead. More than five million have fled abroad during the war. The war has also raised the tension between Sunnis and Shiites in neighbouring Lebanon and Iraq. To ease the tension and resolve the crisis, the United Nations and the Arab League initially tried to dispel the tension in the region. Joint peace envoys were sent by them to persuade both the warring parties to sit for negotiations but with no success. The absence of unity on the international platform is the main reason for the escalation of the Syrian crisis. The disagreements between the international community that are western powers, on the one hand, and Russia and China, on the other hand, has paralyzed the United Nations Security Council to act decisively on the issue (Melling \& Dennett, 2017). With no negotiated settlement in sight, the war is likely to continue until one side prevails militarily.

\section{Conclusion}

The high unemployment rate, poor living conditions, mega corruption, suppression of fundamental rights on the part of dictatorial regimes are the key factors that led to the emergence of the Arab Spring. This series of protests amid to overthrow the authoritarian regimes led to violence and civil war. Moreover, due to such circumstances, instability, uncertainty, and insecurity became the major challenges in the post-uprising period for the Arab world where investors are reluctant to invest and where tourists hesitate to come. Thus, the economic conditions of these countries became much more miserable. Though in most of cases, dictators have been removed, the deteriorating economic conditions and political instability have greatly affected the ordinary people. Revolutions are meant to change the social, economic, and political structure of society. The Arab Spring considered being a revolution that has not brought drastic positive changes to the Arab countries. The world expected a lot from it, but nothing much happened. Currently, we can see somewhat advancement in Tunisia. Egypt, in the beginning, was successful, but again a military coup overthrew the democratically elected government of Morsi. Thus the changes, which were expected from the Arab Spring, did not occur. Democracy in Egypt failed, whereas in Syria, Bashar-ul- Assad still holds power. A civil war is going on in Syria, which does not seem to end in the near future. Most of the countries of the Middle East retain the ruling elites they had before the Arab Spring started. Successful revolutions are very rare, indeed. People's protests in the Arab world were about the abolishment of dictatorial rule by the autocratic regimes, as they wanted their own say in running their countries. An end to the corrupt rulers and participation in the governmental affairs where equal opportunities are provided to them in the setup was the demand of the protesting people. Decades' prolonged suppression by the dictators has frustrated them. The uprising provided them an opportunity to release their anger and frustration against the oppressed ruling elites. Hope was high as, in some cases; the movements were successful in toppling the oppressors but could not be successful in bringing prosperity and economic opportunity to the ordinary people. Instead, the uprisings spread war and chaos across the region.

\section{References}

Abrams, E. (2012). "Dictators go, Monarchs stay", Commentary, 134 (3), 26-31.

Anderson, L. (1991). Absolutism and the resilience of Monarchy in the Middle East. Political Science Quarterly, 106(1), 1-15. DOI: https://doi:10.2307/2152171

Ajami, F. (2011, November). Egypt and the fruits of the Pharaohs, Wall St. J. Retrieved from https://www.wsj.com/articles/SB10001424052970204190504577040013851901598 
Badimon, M. E. (2013). "Does unemployment spark collective contentious action? Evidence from a Moroccan social movement", Journal of Contemporary African Studies, 31 (2), 194-212.

BBC News. (2013, September 24). Middle East.

BBC News. (2016, March 11). Syria: The story of the conflict. Retrieved from https://www.bbc.com/news/world-middle-east-26116868

Breisinger, C., Ecker, O. \& Al-Riffai, P. (2011). "Economics of the Arab awakening". IFPRI Policy Brief, no. 18. Washington, DC: International Food Policy Research Institute. Retrieved from http://www.ifpri.org/publication/economics-arab-awakening

Campante, F. R. \& Chor, D. (2012). "Why was the Arab world poised for revolution? Schooling, economic opportunities, and the Arab Spring." Journal of Economic Perspectives, 26 (2), 167-188.

Comunello, F. \& Anzera, G. (2012, October 1). "Will the revolution be tweeted? A conceptual framework for understanding the social media and the Arab Spring". Islam and Christian-Muslim Relations, 23 (4), 453-470.

Daily News. (2013, December 25). Retrieved fromwww.nydailynews.com/.../al-qaida-linkedgroup-claims-egypt-police-attack...

Dam, N. V. (1979). The struggle for power in Syria: Sectarianism, Regionalism and tribalism in politics, 1961-1978. London: Croom Helm.

Doyle, C. (August 2, 2012). The Guardian.

Frisch, H. (2013). "The role of armies in the Arab uprisings - An introduction", Journal of Strategic Studies, 36 (2), 177-179.

Hill, E. (2013). In Egypt, an unhappy medium. Aljazeera news. Retrieved from http://america.aljazeera.com/articles/2013/10/7/in-egypt-an-unhappymedium.html

Heraldnet. $\quad$ (2013, December 25). from http://www.heraldnet.com/article/20131225/NEWS02/712259884

Hoffman, M. \& Jamal, A. (2012). "The youth and the Arab Spring: Cohort differences and similarities", Middle Eastern Law \& Governance, 4 (1), 168-188.

Joffé, G. (2011). "The Arab Spring in North Africa: Origins and prospects." Journal of North African Studies, 16 (4), 507-532.

Jones, S. G. (2013). "The mirage of the Arab Spring". Foreign Affairs, 92 (1), 55-63.

Khan, A. A. (2012). "The role of social media and modern technology in Arab Spring". Far East Journal of Psychology \& Business, 7 (1), 56-63.

Khondker, H. (2011). "Role of the new media in the Arab Spring". Globalizations, 8 (5), 675679.

Kingsley, P. (2013, June 30). Protesters across Egypt call for Mohamed Morsi to go. The Guardian. Retrieved from https://www.theguardian.com/world/2013/jun/30/mohamed-morsi-egypt-protests

Klare, M.T. (2013, September 10). The Nation.

Kühnhardt, L. (2012). "The resilience of Arab Monarchy." Policy Review, no. 173, 57-67.

Kuhn, R. (2012). "On the role of human development in the Arab Spring". Population and Development Review, 38 (4), 649-683.

Lust, E. (2011, June 1). "Missing the third wave: Islam, institutions, and democracy in the Middle East", Studies In Comparative International Development, 46 (2), 163-190.

Manfred, P. (2011). Retrieved from http://middleeast.about.com

Martin, E. (2012). "On one forgotten cause of the Arab Spring: The lack of economic freedom". Economic Affairs, 32 (3), 94-96. 
Melling, G. \& Dennett, A. (2017). The Security Council veto and Syria: Responding to mass atrocities through the "Uniting for Peace" resolution. Indian Journal of International Law 57, 285-307. Retrieved fromhttps://doi.org/10.1007/s40901018-0084-9

Moore, H. C. (1965). Tunisia since independence: The dynamics of one-party government. Berkeley: University of California Press.

Mulholland, A. (2013, December 28). CTVNews.ca

Ramadan, T. (2011). Egypt: Transition to democracy. In The Arab Spring: Implications for British policy. CMEC. Retrieved from https://cmec.org.uk/sites/default/files/field/attachment/October\%202011\%20CMEC -Arab-Spring.pdf

Salih, O. K. E. (2013). "The roots and causes of the 2011 Arab uprisings". Arab Studies Quarterly, 35 (2), 184-206.

Tariq, H. (2012). Arabs are not ready for democracy: The orientalist cravings of Arab ruling elites. Open Democracy. Retrieved from https://www.opendemocracy.net/en/arabsare-not-ready-for-democracy-orientalist-cravings-of-arab-ruling-elites/

Tessler, M. (2002). "Islam and democracy in the Middle East: The impact of religious orientations on attitudes towards democracy in four Arab countries". Comparative Politics, 34 (3), 337-354.

Tétreault, M. A. (2011). "The winter of the Arab Spring in the Gulf monarchies." Globalizations, 8 (5), 629-637.

The Economist. (2011, February 11). "The Long standoff: The shoe-thrower's index". The Economist. Retrieved from http://www.economist.com/node/18114401

The Economist. (2013, July 13). "The Arab Spring: Has it failed?" Retrieved from https://www.economist.com/leaders/2013/07/13/has-it-failed

The Guardian. (2013, December 25). Egypt declares Muslim Brotherhood a terrorist group. Retrieved from https://www.theguardian.com/world/2013/dec/25/egypt-declaresmuslim-brotherhood-terrorist-group

Valbjorn, M. (2019, April 12).What's so sectarian about sectarian politics? Identity politics and authoritarianism in a new Middle East. Retrieved from https://doi.org/10.1111/sena.12289

Wolfsfeld, G., Segev, E. \& Sheafer, T. (2013). "Social media and the Arab Spring: Politics comes first". International Journal of Press/Politics, 18 (2), 115-137.

Yan, H. (August 30, 2013). CNN News. www.cnn.com/2013/08/29/world/meast/syria-iranchina-russia-supporters/

http://www.economist.com/news/leaders/21581734-despite-chaos-blood-and-democraticsetbacks-long-process-do-not-give-up

Zehraa, S., Fatima, N., \& Khan, N. U. (2018). Iranian-Saudi strategic competition in the Middle East: An analysis of Arab Spring. Liberal Arts and Social Sciences International Journal, 2(2), 59-66.

Zikriya, Khan, \& Salim, 2019). Middle East dilemma: Pakistan's role as mediator for conflict resolution. Liberal Arts and Social Sciences International Journal, 2(2), 59-66. 